\title{
L) UUNiffith
}

Griffith Business School

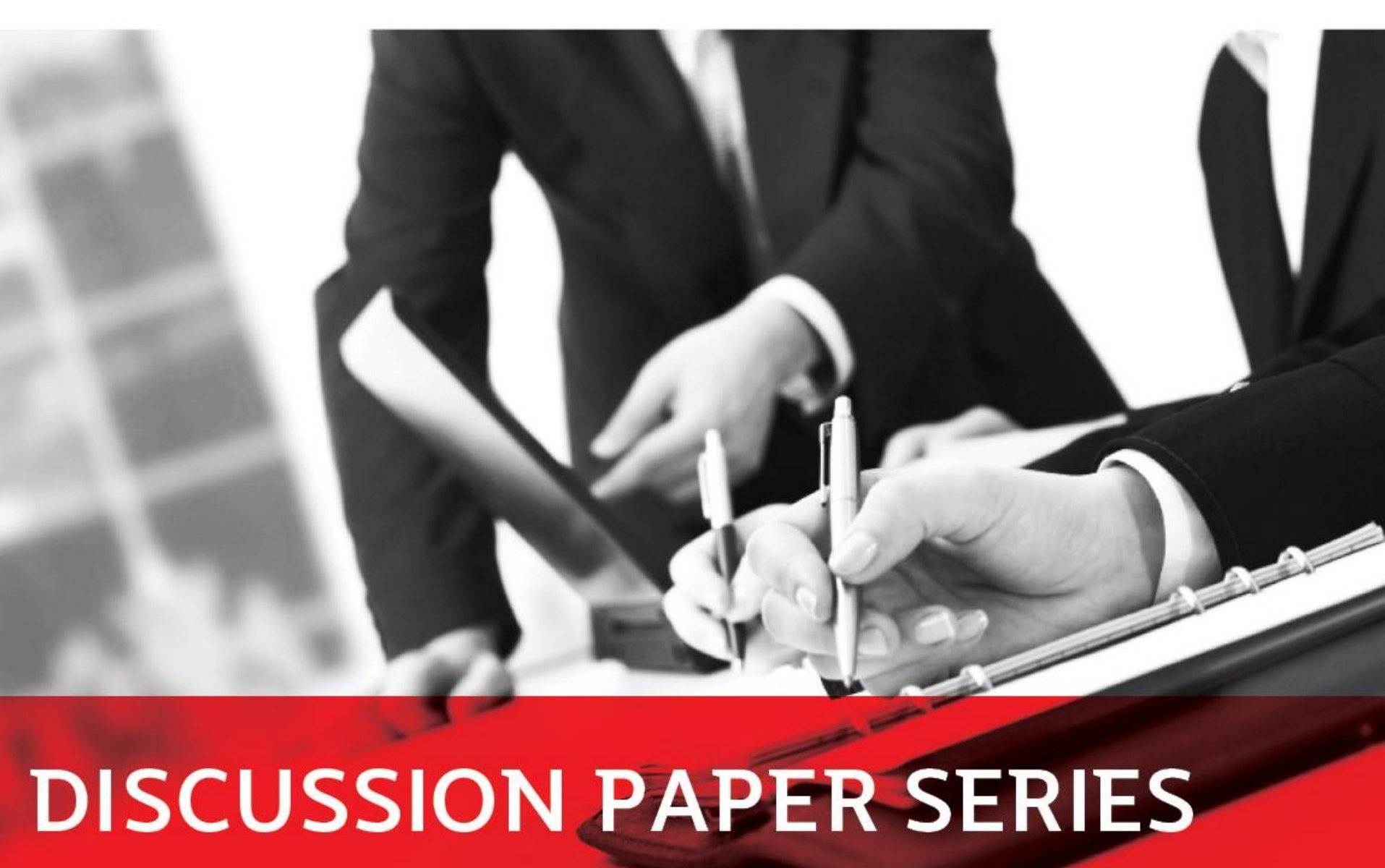

Finance and financial planning

Financial development in less-developed post-communist economies Jakhongir Kakhkharov and Alexandr Akimov

No. $2018-01$ 


\title{
Financial development in less-developed post- communist economies
}

\author{
Jakhongir Kakhkharov \\ Griffith Business School, Griffith University, Australia \\ Alexandr Akimov \\ Griffith Business School, Griffith University, Australia
}

\begin{abstract}
There is wide, albeit equivocal, acceptance that financial development and economic growth are related positively. In his seminal paper, Levine (1997) summarized five functions that assist financial systems to contribute to economic growth. In this paper, we analyze the performance of financial systems in the less-developed post-Communist economies of the former Soviet Union in fulfilling those vital functions, and compare this performance with more advanced transition economies. In general, we find significant progress being made toward building contemporary financial systems in all groups of transition economies, although the gap between financial systems in the less-developed post-Communist countries and their more advanced counterparts remains very large.
\end{abstract}

Key words: Financial institutions, financial development, transition economies

JEL Codes: G21, G28, 016 


\section{Introduction}

One of the groundbreaking events of the $20^{\text {th }}$ century was the demolition of the Berlin Wall, which signaled the beginning of the transition to market economies for the former Communist countries of Central and Eastern Europe. Observers believe that one of the core foundations of the market economy has been the banking system. By channeling funds from savers to borrowers and fulfilling a number of other important roles, a wellfunctioning financial/banking system contributes a significant amount to the economic development of any country.

The progress of reforms in the financial systems of transition economies has been uneven, and many commentators are critical of the reform performance of the postSoviet states. In contrast, for the former Communist countries of Central and Eastern Europe and the Baltics, the literature evaluates the results of banking sector restructuring more favorably (McNulty \& Harper, 2012; Buiter \& Taci, 2005; De Nicoló, Geadah, \& Rozhkov, 2003). Seven countries of the Commonwealth of Independent States (CIS) were distinguished from the rest of the transition countries by multilateral agencies as facing a "particularly difficult transition period" (International Monetary Fund, 2003, p. 1). For these countries - Armenia, Azerbaijan, Georgia, Kyrgyz Republic, Moldova, Tajikistan, and Uzbekistan - the term "CIS-7" was coined. Because Georgia left the CIS in 2008 , this group of countries would now be more appropriately referred to as the "CIS$6+$ Georgia".

The purpose of this study is to compare recent developments in the banking and financial sectors of the distinct groups of countries within Central and Eastern Europe and the former Soviet Union. The focus of attention is the CIS-6 and Georgia. The progress in financial sector development and intermediation is compared with the assistance of various indicators and ratios using the functional approach of Levine (1997). The paper also applies the findings of the existing body of research inquiring into the various aspects of interaction between financial sector development and channels of economic growth to gauge this progress. The study finds that despite a certain amount of progress being made in bridging the gap between advanced transition countries and those lagging behind, further steps involving measures to improve competition and banking practices are required in the latter group of countries.

The paper consists of five sections. Following this introduction, Section 2 briefly reviews the literature relevant to the finance-growth link in transition economies, and then describes the framework for the analysis. Section 3 discusses and compares financial sector development indicators in the less-developed transition economies with those in other transition economies. Section 4 compares economic performance in the various 
groups of transition economies and, finally, Section 5 draws conclusions from these comparisons.

\section{Financial development, economic growth, and the financial systems of transition economies}

There is a large body of theoretical literature supporting a positive link between financial development and economic growth, including seminal papers by Bagehot (1873), Schumpeter and Backhaus (2003), Merton and Bodie (1995), and Levine (1997). Moreover, a large body of empirical work supports a finance-growth nexus in both developed or developing countries (see, for example, Goldsmith, 1969; McKinnon, 1973; King \& Levine, 1993a, 1993b; Odedokun, 1996; Ram, 1999; Benhabib \& Spiegel, 2000; Levine, Loayza, \& Beck, 2000; Rousseau \& Wachtel, 1998). A study by Akimov, Wijeweera, and Dollery (2009) finds a robust positive link between financial development and economic growth in transition economies.

Furthermore, economic research also finds some evidence of the causal relationships running from economic growth to financial development (Jung, 1986; Gurley \& Shaw, 1967), or a two-way causality between growth and finance (Hassan, Sanchez, \& Yu, 2011; Calderón \& Liu, 2003; Demetriades \& Hussein, 1996). In other words, it is possible that an increasing demand for financial services might induce expansion in the financial sector as the real economy grows.

In his seminal paper, Levine (1997) identifies five basic functions of financial systems that contribute to channels of economic growth, that is, capital accumulation and technological innovation. These five functions are: (i) savings mobilization; (ii) resource allocation; (iii) risk management facilitation; (iv) the easing of trading in goods, services and contracts; ( $v$ ) the exertion of corporate control. Thus, how well these functions are fulfilled should determine the impact a financial system has on the economic growth of a particular country. After the collapse of the Eastern bloc, the financial systems of the post-Communist countries have been evolving toward market-oriented capitalist systems. The process of transition has been a focus of attention for many researchers. However, comparative studies of the financial systems in transition have focused mainly on Central and Eastern Europe and the European countries of the former Soviet Union (De Haas et al., 2012; De Haas \& Van Lelyveld, 2006; Bonin, Hasan, \& Wachtel, 2005, 2014; Bonin \& Wachtel, 2003; Berglof \& Bolton, 2002; Hermes \& Lensink, 2000). The financial systems of the poorer countries of the post-Soviet states remain largely unstudied, partially because of a lack of reliable data. 
Recent improvements in data accessibility and coverage offered by the expanded Global Financial Development dataset produced by the World Bank (2017a), Bankscope, and the European Bank for Reconstruction and Development (EBRD) (2017) Life in Transition Survey, sparked efforts to study these so-called "slow transition countries". Some of the comparative research on the financial sectors of the post-Soviet states (excluding the Baltics) and Central Asia comes to the unequivocal conclusion that the development of the financial systems of these countries is lagging behind the most advanced transition countries in the region (McNulty \& Harper, 2012; De Nicoló et al., 2003).

Unlike the previous studies, this research concentrates on the less-developed countries of the CIS by analyzing the differences in the trajectory of development of the financial sector in the CIS-6 and Georgia against more advanced transition economies. The main methodology of the study is the financial ratio analysis using the Levine (1997) functional approach. By reviewing major ratios we attempt to establish whether the financial systems of the selected countries have fulfilled the functions of financial systems well to encourage economic growth.

For the purposes of this research, the transition economies of Central and Eastern Europe and the post-Soviet states are divided into four groups. Thus, 'CIS-6 + Georgia' comprises the least developed countries of the region: Armenia, Azerbaijan, Georgia, the Kyrgyz Republic, Moldova, Tajikistan, and Uzbekistan. The larger economies of the former Soviet Union - Belarus, Kazakhstan, Russia, and Ukraine - are grouped under 'Other CIS'. The third group consists of the transition economies of South Eastern Europe ('SEE'): Albania, Bosnia \& Herzegovina, Bulgaria, Kosovo, Macedonia, Montenegro, Romania, and Serbia. Finally, the most advanced group incorporates those of Central and Eastern Europe and the Baltics ('CEE + Baltics'): Croatia, the Czech Republic, Estonia, Hungary, Latvia, Lithuania, Poland, the Slovak Republic, and Slovenia. The transition countries are divided into these subgroups according to their development level and divisions assessed by previous scholarly research (Berglof \& Bolton, 2002; De Nicoló et al., 2003; McNulty \& Harper, 2012). CIS-6 + Georgia is considered to be the most backward and poor grouping, while CEE + Baltics is the most developed and affluent. The other two groupings, Other CIS and SEE, lie between these two poles.

\section{Performance of financial systems}

\subsection{Savings mobilization}

One of the most important functions of a financial system is the sector's ability to attract savings from surplus units and then to channel them to deficit units. This process is 
known as asset transformation ${ }^{1}$, and financial intermediaries undertake it by creating small-denomination instruments, suitable for small-scale depositors or investors such as households, and investing the proceeds in larger projects required by businesses. To ensure scale efficiency of productive processes, pooling of funding from multiple depositors/investors is often required. However, the mobilization of savings from multiple savers is costly. Transaction costs have to be overcome, typically through economies of scale, and confidence in financial institutions has to be built, so that savers feel comfortable about entrusting their savings to them. Banks play a primary role in attracting households' savings through deposits. In this study, we use two proxies of the ability of the financial sector to mobilize savings. The first is the ratio of bank deposits to GDP, and the second is real deposit rates.

The growth rate in the ratio of bank deposits to GDP in CIS-6 + Georgia has been the highest of all transition countries (see Table 1). Nevertheless, for the most recently observed period, 2006-2011, the value of the ratio in CIS-6 + Georgia constituted only $34 \%$ of that in CEE + Baltics, $40 \%$ of SEE, and $60 \%$ of Other CIS. Moreover, in nominal terms, CIS- 6 + Georgia now lags even further behind all three of the other groups. This increasing divide might be due to various reasons, including a lack of trust in the system or unreliable statistics. Because it is unlikely that the statistical bodies of all the countries under consideration could coordinate simultaneous statistical fabrications, and given a constant increase in the share of the private sector (Turley \& Luke, 2011), it appears that lack of trust is the main culprit, and institutional issues which result in this lack should be investigated.

\footnotetext{
${ }^{1}$ Asset transformation is the process of creating a new asset (loan) from liabilities (deposits) with different characteristics by converting small-denomination and relatively risk-free bank deposits into loans--new relatively risky, large-denomination assets.
} 
Table 1. Bank deposit to GDP ratio

\begin{tabular}{lcccc}
\hline & $\begin{array}{c}\text { Average } \\
\text { 1996-2000 }\end{array}$ & $\begin{array}{c}\text { Average } \\
\mathbf{2 0 0 1 - 2 0 0 5}\end{array}$ & $\begin{array}{c}\text { Average } \\
\mathbf{2 0 0 6 - 2 0 1 1}\end{array}$ & $\begin{array}{c}\text { Average annual } \\
\text { growth rate in \% }\end{array}$ \\
\hline Armenia & 4.8 & 8.3 & 13.2 & 36.7 \\
Azerbaijan & 5.7 & 8.0 & 10.3 & 8.2 \\
Georgia & 3.0 & 6.8 & 16.9 & 62.3 \\
Kyrgyz Republic & 4.6 & 6.1 & 9.7 & 15.1 \\
Moldova & 9.6 & 18.8 & 34.5 & 19.5 \\
Tajikistan & - & 3.6 & 9.0 & 35.6 \\
Uzbekistan & - & - & - & - \\
\hline Average for CIS-6+ Georgia & 5.5 & 9.6 & 16.9 & $\mathbf{2 4 . 8}$ \\
\hline Average for Other CIS & $\mathbf{8 . 9}$ & 15.4 & $\mathbf{2 8 . 1}$ & $\mathbf{1 8 . 0}$ \\
\hline Average for SEE & $\mathbf{1 9 . 8}$ & $\mathbf{2 5 . 3}$ & $\mathbf{4 1 . 4}$ & $\mathbf{6 . 1}$ \\
\hline Average for CEE + Baltics & $\mathbf{3 2 . 1}$ & $\mathbf{4 0 . 4}$ & $\mathbf{4 9 . 1}$ & $\mathbf{5 . 0}$ \\
\hline
\end{tabular}

Source: World Bank (2017a)

Deposit rates are an indicator of the market power of banks (Dermine \& Hillion, 1992). Banks with market power are capable of mobilizing deposit funds in the deposit market at lower costs. Deposit rates in CIS-6 + Georgia have reduced significantly and they are lower than in Other CIS. However, it is important to compare the real deposit rates, that is, taking into account inflation rates. Real deposit rates in CIS-6 + Georgia are comparable with those observed in CEE + Baltics, higher than in Other CIS, and lower than in SEE (see Table 2). However, a closer look at the composition of these averages indicates that there are two distinct outliers in the CIS samples: Tajikistan and Belarus. These two countries are infamous for the high degrees of state intervention in their economies and financial markets, which may have resulted in extreme negative interest rates in both countries. Excluding these two countries increases the average results for both the CIS-6 + Georgia group and that of Other CIS. However, it is interesting to observe that in all groups of transition economies real deposit rates were either negative or only slightly positive. In general, such rates would not encourage the mobilization of savings.

Table 2. Real deposit rates

\begin{tabular}{lcccc}
\hline & Average & Average & Average & Average \\
& 1996-2000 & 2001-2005 & 2006-2010 & 2011-2013 \\
\hline Armenia & 16.4 & 4.3 & 2.2 & 7.6 \\
Azerbaijan & 2.6 & 1.7 & 0.7 & 2.0 \\
Georgia & -4.3 & 0.6 & 3.6 & 7.3 \\
Kyrgyz Republic & 7.5 & 2.1 & -7.5 & -5.5 \\
Moldova & 1.1 & 4.4 & 3.1 & 1.0 \\
Tajikistan & -116.5 & -11.6 & -11.0 & -2.3 \\
Uzbekistan & - & - & - & - \\
\hline Average for CIS-6+ Georgia & -2.4 & 0.2 & -1.5 & 1.7 \\
\hline Average for Other CIS & -46.6 & -12.0 & -6.3 & -12.8 \\
\hline Average for SEE & -29.4 & -3.3 & -0.4 & 1.9 \\
\hline Average for CEE + Baltics & $\mathbf{0 . 9}$ & -0.1 & -0.2 & -0.8 \\
\hline \multicolumn{1}{c}{ Soure: World Bank (2017a) } & & & & \\
\hline
\end{tabular}

Source: World Bank (2017a)

3.2 Resource allocation 
To be able to allocate resources to the most productive use, investors have to overcome informational asymmetry in their evaluation of potential borrowers, managers, and market conditions. Financial intermediaries offer cost savings in information acquisition, and thereby contribute to improved access to capital for borrowers. Moreover, banks should be able to select the projects with the highest growth prospects. In this study, we use four proxies for resource allocation: private credit to GDP ratio, the ratio of nonperforming loans, the ratio of borrowers from commercial banks per 1,000 of adult population, and the percentage of firms using bank financing. Bank credit to the private sector as a ratio to GDP is probably the most important indicator of how the financial system is fulfilling its main function of channeling the funds of savers to productive investment opportunities. It is the private sector which has become the main engine of economic success in industrialized countries. At the macroeconomic level, macroeconomic stabilization, reforms and privatization in the financial sector, and legal reforms are critical determinants of growth in credit to the private sector (Backé \& Zumer, 2005). A study by Djankov, McLiesh, and Shleifer (2007) concludes that legal creditor rights, as well as private and public credit registries, are linked to higher ratios of private credit to gross domestic product.

The Other CIS countries, in particular Ukraine, are leaders among the transition economies in terms of growth in the share of private sector bank credit to GDP ratios. In CIS-6 + Georgia, this ratio is three times smaller than in CEE + Baltics, and only half of SEE's ratio for the period 2006-2011 (see Table 3). Moreover, the lag of CIS $6+$ Georgia behind all of the other three groups has increased over the period from 1996 to 2011. Because macroeconomic stabilization has been achieved in all countries in the sample, delays in the privatization of the financial sector, as well as legal reforms, may account for this phenomenon.

Table 3. Bank credit to private sector to GDP ratio

\begin{tabular}{lcccc}
\hline & $\begin{array}{c}\text { Average } \\
\text { 1996-2000 }\end{array}$ & $\begin{array}{c}\text { Average } \\
\mathbf{2 0 0 1 - 2 0 0 5}\end{array}$ & $\begin{array}{c}\text { Average } \\
\mathbf{2 0 0 6 - 2 0 1 1}\end{array}$ & $\begin{array}{c}\text { Average annual } \\
\text { growth rate in \% }\end{array}$ \\
\hline Armenia & 6.9 & 6.6 & 18.3 & 35.0 \\
Azerbaijan & 2.5 & 6.3 & 14.0 & 92.0 \\
Georgia & 4.5 & 8.4 & 26.6 & 44.8 \\
Kyrgyz Republic & 5.4 & 4.9 & 10.0 & 2.1 \\
Moldova & 9.1 & 16.9 & 31.3 & 23.1 \\
Tajikistan & & 12.1 & 16.0 & 8.0 \\
Uzbekistan & - & - & - & - \\
\hline Average for CIS-6 + Georgia & 5.7 & 9.2 & 19.4 & 34.2 \\
\hline Average for Other CIS & 6.8 & 16.4 & 40.4 & 89.7 \\
\hline Average for SEE & 15.1 & 15.5 & 41.0 & 26.0 \\
\hline Average for CEE + Baltics & 29.3 & 35.7 & 60.5 & 22.5 \\
\hline
\end{tabular}

Source: World Bank (2017a)

The non-performing loan (NPL) ratio reflects how well banks fulfill the function of selecting good projects. High NPL ratios signal issues with supervision, regulation, and 
lending practices, as well as a slow pace in bank reform, which may affect the quality of bank lending adversely (De Nicoló et al., 2003). A recent study of the relationship between NPL ratios and macroeconomic conditions, such as GDP growth, unemployment, and inflation, in Central, Eastern, and South Eastern Europe indicates that the level of NPL ratios could be attributed to both macroeconomic conditions and bank-specific factors (Klein, 2013). The recent increase in NPL ratios in Central, Eastern, and South Eastern Europe, as illustrated in Table 4, may be the result of the slow pace of economic recovery following the 2008 global financial crisis.

On the surface, NPL ratio levels in CIS-6 + Georgia appear low compared to other transition regions. However, at least one country in this group (Uzbekistan) is infamous for improper classification of NPLs, resulting in their severe underestimation. One of the reasons for this is the general preference of banks to roll over or restructure problematic loans rather than classify them as non-performing (Akimov \& Dollery, 2009). The World Bank, with reference to Moody's, reported that the actual ratio of NPLs was about 10 percent in Uzbekistan (World Bank, 2014). Another reason could be a prevalence of collateralized loans in this group, which should improve loan repayment but may have an adverse effect on total loans. This is because collateral requirements restrict access to credit to those who can afford to allocate the collateral required by banks.

Table 4. Bank non-performing loans to total gross loans (\%)

\begin{tabular}{lcccc}
\hline & $\begin{array}{c}\text { Average } \\
\text { 1998-2000 }\end{array}$ & $\begin{array}{c}\text { Average } \\
\mathbf{2 0 0 1 - 2 0 0 5}\end{array}$ & $\begin{array}{c}\text { Average } \\
\mathbf{2 0 0 6 - 2 0 1 0}\end{array}$ & $\begin{array}{c}\text { Average } \\
\text { 2011-2014 }\end{array}$ \\
\hline Armenia & 10.5 & 8.7 & 3.4 & 4.4 \\
Azerbaijan & & 16.3 & 4.1 & 5.4 \\
Georgia & & 5.0 & 3.6 & 3.7 \\
Kyrgyz Republic & 24.0 & 11.5 & 7.8 & 6.9 \\
Moldova & 20.6 & 7.9 & 8.6 & 12.2 \\
Tajikistan & & & 7.7 & 10.9 \\
Uzbekistan & & 3.0 & 1.7 & 0.4 \\
\hline Average for CIS-6+Georgia & 18.4 & 8.7 & 5.3 & 6.3 \\
\hline Average for Other CIS & 18.8 & 12.7 & 11.7 & 11.4 \\
\hline Average for SEE & 30.2 & 10.2 & 7.3 & 15.8 \\
\hline Average for CEE + Baltics & 10.9 & 5.7 & 5.5 & 9.4 \\
\hline
\end{tabular}

Source: World Bank (2017a)

The dataset for the number of borrowers from commercial banks is fragmented (see Table 5) and is not available for Other CIS. The data that is available shows that some countries of CIS-6 + Georgia, such as the Kyrgyz Republic, Moldova, Tajikistan, and Uzbekistan, have the lowest ratios of borrowers to 1,000 adults among the transition economies. Only Kosovo's ratio is lower than that of these countries. The low ratio of borrowers in Uzbekistan indirectly confirms the conjecture discussed in Section 3.4, that is, that the figures for bank branch penetration for this country may be erroneous. One of the main consequences of a high branch penetration should be an increase in the ratio of borrowers because lending is still considered one of the main functions of banking 
activity. It should also be noted that Georgia made significant progress in this ratio over the period starting in 2004, immediately after the "Rose Revolution"2. Overall, most of CIS-6 + Georgia appear to fare significantly worse than the rest of the transition countries.

Table 5. Borrowers from commercial banks (per 1,000 adults)

\begin{tabular}{|c|c|c|c|c|c|c|c|c|c|}
\hline & 2004 & 2005 & 2006 & 2007 & 2008 & 2009 & 2010 & 2011 & 2012 \\
\hline Armenia & 69.4 & 92.9 & 114.4 & 159.8 & 190.4 & 162.7 & 201.0 & 258.4 & \\
\hline Azerbaijan & & 20.0 & 33.4 & 58.1 & 76.4 & 68.1 & 81.1 & 109.6 & 151.3 \\
\hline Georgia & 32.1 & 48.5 & 90.7 & 160.0 & 210.2 & 239.9 & 288.2 & 386.6 & 405.9 \\
\hline Kyrgyz Republic & & & & & & 22.6 & 29.1 & 36.7 & 40.3 \\
\hline Moldova & 15.6 & 27.9 & 37.6 & 60.1 & 64.0 & 43.4 & 38.0 & 37.1 & 41.5 \\
\hline Tajikistan & 3.5 & 7.9 & 12.0 & 24.3 & 29.3 & 18.0 & 21.0 & 24.4 & 30.0 \\
\hline Uzbekistan & & & 12.6 & 21.5 & 24.9 & 26.9 & 36.5 & 39.8 & 44.5 \\
\hline $\begin{array}{l}\text { Average for } \\
\text { CIS-6 + Georgia }\end{array}$ & 39.0 & 47.3 & 69.0 & 109.5 & 135.2 & 107.3 & 109.7 & 165.7 & 159.7 \\
\hline $\begin{array}{l}\text { Average for } \\
\text { SEE }\end{array}$ & 8.4 & 16.3 & 29.7 & 114.0 & 173.5 & 169.6 & 184.0 & 186.7 & 189.4 \\
\hline $\begin{array}{l}\text { Average for } \\
\text { CEE + Baltics }\end{array}$ & 126.4 & 130.9 & 163.2 & 199.7 & 341.1 & 354.4 & 439.4 & 423.2 & 455.8 \\
\hline
\end{tabular}

The percentage of firms using banks to finance investments is another indicator measuring the access to finance that businesses enjoy in different countries (see Table 6). CIS-6 + Georgia lags behind in this indicator too, but the divide between CIS-6 + Georgia and the rest of the transition countries is not large. The averages for this indicator have shrunk since 2005 by comparison with CEE + Baltics, which recorded a small amount of growth over the same period. As to the other groups of economies (Other CIS and SEE), the differences in this indicator have fluctuated considerably throughout the entire observation period. Also of note is that the number of firms using banks to finance investments fell significantly in 2013 in almost all of the transition countries in the aftermath of the global financial crisis.

Overall, it appears that financial intermediaries in CIS-6 + Georgia have been less effective and efficient in fulfilling the function of resource allocation.

Table 6. Firms using banks to finance investments (\% of total)

\begin{tabular}{lcccc}
\hline & $\mathbf{2 0 0 2}$ & $\mathbf{2 0 0 5}$ & $\mathbf{2 0 0 8 / 2 0 0 9}$ & $\mathbf{2 0 1 3}$ \\
\hline Armenia & 5.6 & 44.6 & 31.9 & 18.6 \\
Azerbaijan & 3.9 & 0.4 & 19.0 & 27.6 \\
Georgia & 23.4 & 40.0 & 38.2 & 22.0 \\
Kyrgyz Republic & 9.0 & 13.6 & 17.9 & 18.5 \\
Moldova & 26.6 & 27.0 & 30.8 & 19.7 \\
Tajikistan & 4.3 & 1.3 & 21.4 & 13.4 \\
Uzbekistan & 1.4 & 8.2 & 8.2 & 16.2 \\
\hline
\end{tabular}

\footnotetext{
2 The Revolution of Roses (often translated into English as the Rose Revolution) refers to a change of power in Georgia in November 2003, which took place after widespread protests over disputed parliamentary elections.
} 


\begin{tabular}{lcccc}
\hline Average for CIS- 6 + Georgia & 13.7 & 25.1 & 23.9 & 19.4 \\
\hline Average for Other CIS & 11.7 & 23.4 & 32.4 & 24.7 \\
\hline Average for SEE & 15.9 & 32.0 & 46.1 & 26.3 \\
\hline Average for CEE + Baltics & 23.1 & 30.9 & 41.8 & 28.3 \\
\hline
\end{tabular}

Source: World Bank (2017a)

\subsection{Risk management facilitation}

Another important function of financial institutions is to facilitate risk management by providing vehicles for trading, pooling, and diversifying risks, including liquidity risk, credit risk, and other project-related risks. How well a financial system executes this function affects long-term economic growth by altering resource allocation and savings rates. Financial institutions are in charge of developing vehicles for resource allocations in risky projects that would not be otherwise funded. For example, venture capital is critical for making technological advancements (Levine, 1997). In this study, four indicators are examined to see how well this function is fulfilled. First, the ratio of M2 (money and quasimoney) to GDP is the proxy for the liquidity available to market participants. Second, stock market to GDP ratio is a measure of stock market development in the economy. The stock market is a critical conduit for pooling, trading, and diversifying risk. Third and fourth, the indicator of proportion of loans requiring collateral and the liquid asset ratio indicate the appetite of banks for taking credit risk.

The growth rate in M2 to GDP ratio in CIS-6 + Georgia in the period from 1996 to 2013 is the second highest behind the Other CIS group (see Table 7). While the values of this indicator for Tajikistan and Uzbekistan are much lower than the average, the figure for Moldova is almost the same as that of SEE and close to the level of CEE + Baltics. This confirms that a significant level of divergence exists within the CIS-6 + Georgia group. Despite the fact that, in general, CIS-6 + Georgia still trails behind the most advanced transition countries in the region in the average values of this indicator, the positive trend in monetization level is contrary to the negative growth rate in this indicator noted by De Nicoló et al. (2003) using the data available at the end of 2002.

It is noteworthy that in most high-income countries with well-developed banking sectors, the ratio of broad money to GDP is much higher than in the transition countries examined in this research. For example, according to World Bank (2017b) World Development Indicators (WDI), M2/GDP in the Eurozone countries was not less than 150 percent throughout the period 2007-2013. 
Table 7. M2 to GDP ratio, 1996-2013

\begin{tabular}{|c|c|c|c|c|c|}
\hline & $\begin{array}{c}\text { Average } \\
1996-2000\end{array}$ & $\begin{array}{c}\text { Average } \\
2001-2005\end{array}$ & $\begin{array}{c}\text { Average } \\
2006-2010\end{array}$ & $\begin{array}{c}\text { Average } \\
2011-2013\end{array}$ & $\begin{array}{c}\text { Average annual } \\
\text { growth rate in } \\
\%\end{array}$ \\
\hline Armenia & 10.6 & 14.9 & 22.5 & 33.2 & 18.9 \\
\hline Azerbaijan & 12.8 & 14.5 & 21.8 & 30.4 & 10.9 \\
\hline Georgia & 8.2 & 13.7 & 24.8 & 32.0 & 24.3 \\
\hline Kyrgyz Republic & 13.4 & 17.0 & 28.9 & 31.6 & 10.3 \\
\hline Moldova & 20.5 & 32.8 & 50.2 & 56.1 & 13.4 \\
\hline Tajikistan & 8.1 & 10.2 & 17.8 & 20.1 & 8.3 \\
\hline Uzbekistan & 15.9 & 12.1 & 18.1 & 24.3 & 1.1 \\
\hline $\begin{array}{l}\text { Average for CIS-6 + } \\
\text { Georgia }\end{array}$ & 12.8 & 16.5 & 26.3 & 32.5 & 10.2 \\
\hline Average for Other CIS & 16.6 & 25.5 & 40.5 & 44.2 & 13.3 \\
\hline Average for SEE & 30.4 & 33.9 & 50.6 & 56.6 & 6.1 \\
\hline $\begin{array}{l}\text { Average for CEE + } \\
\text { Baltics }\end{array}$ & 38.1 & 47.1 & 57.1 & 62.9 & 4.0 \\
\hline
\end{tabular}

Source: World Bank (2017a) and Asian Development Bank (2017)

Although there is well-documented empirical evidence of the importance of the stock market for economic growth (Atje \& Jovanovic, 1993; Levine \& Zervos, 1998), a number of studies point to the negative influence of the stock market on economic development, which is manifested by the stimulation of investments predominantly in short-term projects (Stein, 1989). Furthermore, liquid stock markets may facilitate hostile takeovers, which decrease the efficiency of resource allocation (Levine, 1997). Given the small size of the economies of the majority of the transition countries, some authors argue that stock markets are unlikely to make a significant contribution to financial market development (Bonin \& Wachtel, 2003).

Despite a transition lasting a quarter of a century, stock markets still play a very minor role in allocating funds in all of the transition countries, as illustrated in Table 8. Evidence suggests that transition economies typically choose a bank-led financial system, because stock markets require strong institutions (Akimov \& Dollery, 2008). However, in CIS-6 + Georgia, the stock markets are very small even by comparison with the other transition countries. It has been noted that this ratio is highest among those countries where the privatization process has made significant progress, and this may give a misleading indication of the maturity of the equity market (Bonin \& Wachtel, 2003). It should also be noted that there is some evidence that a higher level of financial openness spurs equity market development only if a minimum threshold of legal development has also been attained. In addition, Chinn and Ito (2006) found that the development of the banking system is a precondition for equity market development. As will be demonstrated below, on many counts of institutional development, including legal development, CIS-6 + Georgia lag significantly behind. 
Table 8. Stock market capitalization to GDP (\%)

\begin{tabular}{lccc}
\hline & Average 1996-2000 & Average 2001-2005 & $\mathbf{2 0 1 1}$ \\
\hline Armenia & 0.6 & 1.3 & 1.4 \\
Azerbaijan & - & - & - \\
Georgia & 3.4 & 7.3 & 6.8 \\
Kyrgyz Republic & 0.9 & 2.1 & 2.0 \\
Moldova & - & - & - \\
Tajikistan & - & - & - \\
Uzbekistan & - & 3.6 & - \\
\hline Average for CIS-6 + Georgia & 1.6 & $\mathbf{4 6 . 2}$ & $\mathbf{3 . 4}$ \\
\hline Average for Other CIS & 18.2 & 33.7 & $\mathbf{3 2 . 6}$ \\
\hline Average for SEE & $\mathbf{8 . 1}$ & $\mathbf{2 5 . 8}$ & $\mathbf{1 7 . 5}$ \\
\hline Average for CEE + Baltics & $\mathbf{1 8 . 5}$ & &
\end{tabular}

The high percentage of firms required to pledge collateral to borrow funds from banks may be an explanation for why there is a difference in the ratio of private sector bank credit to GDP, and in the percentages of firms using banks to finance investments, between CIS- 6 + Georgia and other transition countries. While collateral seems to be a dominant feature of loan agreements in virtually all of the transition countries, this percentage is higher in the post-Soviet states, with the exception of the Baltics. For many SMEs in transition countries, collateral may be an insurmountable hurdle in obtaining funds. The share of loans requiring collateral has decreased significantly over time in $\mathrm{CEE}+$ Baltics and SEE. Although this ratio decreased in CIS-6 + Georgia as well, the decline has been marginal: whereas the percentage of loans requiring collateral decreased from $87.2 \%$ to $86.1 \%$ in CIS- 6 + Georgia, in CEE + Baltics the reduction was from $79.8 \%$ to $72.9 \%$.

One of the main reasons why collateral is still prevalent in some of the transition countries is the acuteness of asymmetric information problem, giving rise to moral hazard problems in these countries. Low accounting standards make it difficult to undertake a proper credit risk assessment of clients (Burns \& Needles, 1994). In consequence, banks prefer to rely on tangible collateral rather than credit risk analysis. This also makes banks in CIS-6 + Georgia less willing to take on credit risk. 
Table 9. Loans requiring collateral (\% of total)

\begin{tabular}{lccc}
\hline & $\mathbf{2 0 0 2}$ & $\mathbf{2 0 0 5}$ & $\mathbf{2 0 0 8 / 2 0 0 9}$ \\
\hline Armenia & 84.6 & 73.3 & 85.9 \\
Azerbaijan & 85.2 & 82.1 & 87.2 \\
Georgia & 91.1 & 91.4 & 87.3 \\
Kyrgyz Republic & 76.5 & 93.2 & 85.1 \\
Moldova & 98.5 & 92.3 & 85.1 \\
Tajikistan & 67.4 & 76.5 & 84.1 \\
Uzbekistan & 83.5 & 75.6 & 98.7 \\
\hline Average for CIS-6 + Georgia & $\mathbf{8 7 . 2}$ & $\mathbf{8 6 . 5}$ & $\mathbf{8 6 . 1}$ \\
\hline Average for Other CIS & $\mathbf{8 5 . 6}$ & $\mathbf{8 9 . 7}$ & $\mathbf{8 9 . 2}$ \\
\hline Average for SEE & $\mathbf{8 5 . 4}$ & $\mathbf{9 3 . 8}$ & $\mathbf{8 0 . 1}$ \\
\hline Average for CEE + Baltics & $\mathbf{7 9 . 8}$ & $\mathbf{8 2 . 5}$ & $\mathbf{7 2 . 9}$ \\
\hline \multicolumn{1}{c}{ Source: World Bank (2017a) } & & &
\end{tabular}

To manage their liquidity risk, banks maintain a proportion of their assets in liquid instruments. Liquid assets assist banks in covering a sudden deposit outflow or a cutoff in short-term funding. Liquid assets also assist in situations where banks cannot anticipate new loan demand and do not have quick access to sources of cash. On the other hand, liquid assets have large opportunity costs because they produce low returns. Therefore, banks with stable access to interbank market liquidity keep their liquid assets to a minimum. Table 10 illustrates that banks in CIS-6 + Georgia have a higher ratio of liquid assets to deposits and short-term funding, and thus hedged better against liquidity risk when compared to other transition regions. However, it is likely that these high ratios are the result of underdeveloped interbank lending and money markets.

Table 10. Liquid assets to deposits and short-term funding (\%)Table 10.

\begin{tabular}{lcccc}
\hline & $\begin{array}{c}\text { Average } \\
\text { 1998-2001 }\end{array}$ & $\begin{array}{c}\text { Average } \\
\mathbf{2 0 0 1 - 2 0 0 5}\end{array}$ & $\begin{array}{c}\text { Average } \\
\mathbf{2 0 0 6 - 2 0 0 9}\end{array}$ & $\begin{array}{c}\text { Average } \\
\mathbf{2 0 1 0 - 2 0 1 1}\end{array}$ \\
\hline Armenia & 44.8 & 66.3 & 39.7 & 32.5 \\
Azerbaijan & 48.3 & 45.0 & 37.8 & 29.4 \\
Georgia & 46.0 & 47.6 & 36.8 & 23.5 \\
Kyrgyz Republic & 67.0 & 75.6 & 59.2 & 59.5 \\
Moldova & 45.2 & 40.9 & 31.6 & 23.6 \\
Tajikistan & & 53.6 & 43.2 & 28.2 \\
Uzbekistan & 32.7 & 52.4 & 38.7 & 42.2 \\
\hline Average CIS-6+ Georgia & 47.3 & 54.5 & 41.0 & 34.1 \\
\hline Average Other CIS & 41.5 & 34.4 & 35.4 & 34.1 \\
\hline Average SEE & 74.1 & 53.6 & 36.5 & 27.0 \\
\hline Average CEE + Baltics & 46.7 & 39.5 & 28.8 & 23.0 \\
\hline
\end{tabular}

Source: Bankscope

3.4 Easing of trading in goods, services and contracts

Financial intermediaries play an important role in creating easy, convenient and low-cost payment facilities that promote trading in goods, services and contracts. This, in turn, has two important influences that feed through to the facilitation of economic activity. First, it encourages specialization and productivity growth. Second, it lowers the costs of running business and expands sales markets, thereby encouraging investment in new 
production facilities. Three measures are used in this study as proxies for how prominent banks are in advancing this function. These are ATM penetration, the number of bank accounts per 1,000 adults, and the number of bank branches per 1,000 adults.

Table 11 illustrates that CIS-6 + Georgia has very low ATM services penetration rates. The numbers of ATMs per 100,000 of population are especially low in Uzbekistan and Tajikistan. However, even discounting these two countries, the ratio remains noticeably lower for CIS-6 + Georgia than for South Eastern Europe, the next worst region in terms of ATM penetration.

Table 11. ATMs per 100,000 of population

\begin{tabular}{|c|c|c|c|c|c|c|c|c|}
\hline & 2004 & 2005 & 2006 & 2007 & 2008 & 2009 & 2010 & 2011 \\
\hline Armenia & 3.0 & 4.8 & 7.5 & 13.9 & 22.0 & 28.5 & 32.0 & 40.9 \\
\hline Azerbaijan & - & - & 16.6 & 19.8 & 22.1 & 24.0 & 26.4 & 29.8 \\
\hline Georgia & 1.9 & 5.2 & 12.1 & 23.1 & 36.6 & 37.2 & 40.4 & 42.2 \\
\hline Kyrgyz Republic & 0.6 & 1.0 & 1.2 & 2.4 & 4.7 & 8.4 & 7.3 & 12.1 \\
\hline Moldova & & & & & & & 25.8 & 28.7 \\
\hline Tajikistan & 0.7 & 0.7 & 1.4 & 2.2 & 3.0 & 4.0 & 5.1 & 7.7 \\
\hline Uzbekistan & 0.9 & 1.0 & 1.0 & 0.9 & 0.9 & 1.9 & 2.5 & 4.5 \\
\hline $\begin{array}{l}\text { Average for CIS-6 } \\
+ \text { Georgia }\end{array}$ & 1.4 & 2.5 & 6.6 & 10.4 & 14.9 & 17.3 & 19.9 & 23.7 \\
\hline $\begin{array}{l}\text { Average for Other } \\
\text { CIS }\end{array}$ & 14.3 & 20.3 & 26.9 & 40.0 & 54.6 & 60.1 & 76.6 & 85.9 \\
\hline Average for SEE & 15.1 & 16.1 & 24.8 & 35.1 & 45.4 & 51.0 & 51.4 & 52.7 \\
\hline $\begin{array}{l}\text { Average for CEE } \\
+ \text { Baltics }\end{array}$ & 45.5 & 49.9 & 54.0 & 60.0 & 64.4 & 66.9 & 68.7 & 68.2 \\
\hline
\end{tabular}

Data on bank accounts per 1,000 adults (see Table 12) is not available for South Eastern Europe. It seems curious that Uzbekistan ranked worst in ATM penetration rates but boasts the second highest number of bank accounts per 1,000 adults. This is most probably due to deficiencies in recording this statistic in Uzbekistan. Some transactions in Uzbekistan require the opening of one or two bank accounts for what are, essentially, one-off transactions, for example, purchase of a car for foreign currency, or conversion of a local currency into a hard currency. These accounts typically become dormant as soon as the transaction has been completed. Besides this phenomenon, a portion of the salaries in Uzbekistan are transferred to debit cards via bank accounts, even though the customers never use these bank accounts for any transactions. Such accounts are needed to accomplish only the transfer of funds to debit cards and are not used on a daily basis. Therefore, although the purpose and the use of these bank accounts resembles that in any other country, in Uzbekistan these bank accounts are severely underutilized. Overall, CIS-6 + Georgia compares unfavorably with other transition countries in the indicator of banking services accessibility.

Table 12. Bank accounts per 1,000 adults

$2004-2005-2006$

$\begin{array}{llllll}2006 & 2007 & 2008 & 2009 & 2010 & 2011\end{array}$




\begin{tabular}{|c|c|c|c|c|c|c|c|c|}
\hline Armenia & 212.2 & 356.3 & 365.2 & 454.1 & 461.4 & 521.3 & 586.1 & 711.4 \\
\hline Azerbaijan & & 91.1 & 140.0 & 188.7 & 255.0 & 295.7 & 352.0 & 398.2 \\
\hline Georgia & 187.8 & 314.2 & 385.7 & 430.5 & 480.4 & 509.8 & 571.7 & 650.8 \\
\hline Kyrgyz Republic & & & & & & 74.6 & 100.9 & 155.2 \\
\hline Moldova & 788.6 & 847.5 & 903.9 & 1015.6 & 1096.7 & 1134.2 & 1208.4 & 1167.0 \\
\hline Tajikistan & 183.4 & 212.9 & 353.5 & 263.2 & 262.7 & 365.5 & 413.7 & 474.9 \\
\hline Uzbekistan & 520.7 & 679.5 & 816.4 & 869.2 & 886.9 & 900.4 & 942.3 & 959.2 \\
\hline $\begin{array}{l}\text { Average for CIS-6 } \\
+ \text { Georgia }\end{array}$ & 396.2 & 402.3 & 448.7 & 522.2 & 573.4 & 507.1 & 538.8 & 616.5 \\
\hline $\begin{array}{l}\text { Average for Other } \\
\text { CIS }\end{array}$ & 722.4 & 1769.1 & 1872.3 & 1994.3 & 2025.1 & 2051.3 & 2050.1 & 2187.0 \\
\hline $\begin{array}{l}\text { Average for CEE } \\
+ \text { Baltics }\end{array}$ & 920.1 & 930.7 & 1022.4 & 1158.8 & 1445.1 & 1649.7 & 1567.2 & 1542.5 \\
\hline
\end{tabular}

The bank branch penetration ratio (see Table 13) puts CIS-6 + Georgia in third spot, a respectable distance ahead of the region's worst performer, Other CIS. The growth rate in this ratio for the region seems to be steady and stable. However, a closer look at this statistic indicates that the leading countries in the region for this parameter are Bulgaria and Uzbekistan. In terms of numbers of bank branches, these countries were ahead of Germany (15.7 branches per 100,000 adults), USA (35.43), and France (41.58). However, again, the figure for Uzbekistan may be erroneous and may include small cashiers and foreign exchange desks as well as very small mini-bank branches consisting of two to three bank employees. To confirm the possibility of an error, the website of each major bank was checked. The bank with the most extensive network in Uzbekistan (Halk Bank) has only 202 branches. The majority of the other 25 banks in Uzbekistan have only a few branches. Even if all other Uzbekistan banks were assumed to have at least the same number of branches as Halk Bank, then given the WDI estimates for the total population of Uzbekistan of about 30 million, and an adult population of 22.5 million, the number of branches per 100,000 adults would still be only 22.4 (rather than 46.8). Excluding Uzbekistan, the number of bank branches per 100,000 adult population of the CIS-6 + Georgia group is significantly worse than the rest of the transition countries: the ratio for CIS-6 + Georgia drops to 11.5 - almost equal to the ratio of the worst performer, Other CIS. 
Table 13. Bank branches per 100,000 adults

\begin{tabular}{|c|c|c|c|c|c|c|c|c|c|c|}
\hline & 2004 & 2005 & 2006 & 2007 & 2008 & 2009 & 2010 & 2011 & $\begin{array}{l}\text { Average } \\
2004-07\end{array}$ & $\begin{array}{l}\text { Average } \\
2008-11\end{array}$ \\
\hline Armenia & 10.7 & 12.0 & 13.3 & 15.2 & 16.5 & 16.8 & 17.4 & 18.8 & 12.8 & 17.4 \\
\hline Azerbaijan & 6.4 & 6.6 & 7.1 & 8.0 & 8.9 & 9.5 & 9.6 & 9.9 & 7.0 & 9.5 \\
\hline Georgia & 9.2 & 10.3 & 12.1 & 15.4 & 19.3 & 17.8 & 17.8 & 19.6 & 11.7 & 18.6 \\
\hline Kyrgyz Republic & 5.1 & 5.3 & 5.3 & 6.4 & 6.9 & 6.9 & 6.1 & 7.3 & 5.6 & 6.8 \\
\hline Moldova & 7.3 & 7.8 & 8.3 & 9.2 & 10.7 & 10.2 & 10.4 & 11.3 & 8.1 & 10.6 \\
\hline Tajikistan & 5.3 & 5.5 & 5.6 & 5.6 & 6.0 & 5.9 & 6.2 & 6.7 & 5.5 & 6.2 \\
\hline Uzbekistan & 39.4 & 40.3 & 42.7 & 44.8 & 45.8 & 46.8 & 46.8 & 47.7 & 41.8 & 46.8 \\
\hline $\begin{array}{l}\text { Average for CIS-6 + } \\
\text { Georgia }\end{array}$ & 7.7 & 8.4 & 9.2 & 10.8 & 12.4 & 12.2 & 11.2 & 13.4 & 13.2 & 16.5 \\
\hline Average for Other CIS & 10.0 & 10.5 & 10.7 & 11.5 & 11.9 & 11.3 & 11.1 & 11.0 & 10.7 & 11.3 \\
\hline Average for SEE & 27.5 & 28.3 & 29.7 & 33.4 & 37.2 & 37.1 & 36.4 & 30.9 & 29.8 & 35.4 \\
\hline $\begin{array}{l}\text { Average for CEE + } \\
\text { Baltics }\end{array}$ & 25.5 & 26.3 & 27.1 & 28.4 & 29.1 & 28.5 & 27.7 & 27.3 & 26.8 & 28.2 \\
\hline
\end{tabular}

\subsection{Exertion of corporate control}

One of the key challenges faced by investors is ensuring that firms (borrowers) act in the best interest of the lenders. Asymmetric information and high monitoring costs prevent the majority of investors from ensuring this for themselves. In turn, lack of appropriate arrangements to exert corporate control may impede mobilization of savings and prevent capital flowing to profitable investments (Stiglitz \& Weiss, 1981, 1983). In addition, a legal and institutional environment that protects investors' interests is crucial, so that investors are comfortable in extending their capital.

The quality of institutions, characteristics of governance, and efficiency of regulatory environments and policies could have a tremendous impact on economic growth, including the performance of the financial/banking sector (Acemoglu, Johnson, \& Robinson, 2005). Therefore, the focus of this section is on the indicators of institutional quality that may have had an impact on financial development in transition countries. Demirgüç-Kunt and Detragiache (1998) argue that financial liberalization increases the probability of a banking crisis, but less so where the institutional environment is strong, as measured by the rule of law, a low level of corruption, and good contract enforcement.

In this study, because of an absence of financial institution-specific measures of governance, we focus on broader governance measures for the economies, which include strength of legal rights, depth of credit information, regulatory quality, rule of law, and control of corruption.

The figures for the strength of legal rights index, as shown in Table 14, reflect a divide between the different countries constituting CIS-6 + Georgia. This coefficient has been particularly low for Uzbekistan and Tajikistan, and the regression in Azerbaijan during the period 2004-2014 is also notable. Other countries of the CIS-6 + Georgia group fare 
quite well by comparison with the other transition country groups. On the other hand, significant progress by CIS-6 + Georgia has been witnessed in the depth of credit information index (see Table 14): as of 2014, the region is ranked second behind Other CIS in this regard.

Table 14. Strength of legal rights index $(0=$ weak to $12=$ strong $)$ and Depth of credit information index $(0=$ low to $8=$ high $)$

\begin{tabular}{|c|c|c|c|c|c|c|}
\hline & \multicolumn{3}{|c|}{ Strength of legal rights index } & \multicolumn{3}{|c|}{ Depth of credit information index } \\
\hline & $\begin{array}{c}\text { Average } \\
\text { 2004-2008 }\end{array}$ & $\begin{array}{c}\text { Average } \\
2009-2013\end{array}$ & 2014 & $\begin{array}{c}\text { Average } \\
\text { 2004-2008 }\end{array}$ & $\begin{array}{c}\text { Average } \\
2009-2013\end{array}$ & 2014 \\
\hline Armenia & 5.6 & 5.8 & 5.0 & 2.0 & 6.0 & 8.0 \\
\hline Azerbaijan & 5.0 & 4.4 & 2.0 & 0.0 & 5.2 & 6.0 \\
\hline Georgia & 5.2 & 7.8 & 9.0 & 0.0 & 6.4 & 8.0 \\
\hline Kyrgyz Republic & 6.6 & 9.6 & 8.0 & 0.0 & 4.2 & 5.0 \\
\hline Moldova & 8.0 & 8.0 & 8.0 & 0.0 & 0.0 & 6.0 \\
\hline Tajikistan & 3.0 & 2.2 & 1.0 & 0.0 & 0.0 & 6.0 \\
\hline Uzbekistan & 2.0 & 1.8 & 1.0 & 0.0 & 2.8 & 7.0 \\
\hline \multicolumn{7}{|l|}{$\begin{array}{l}\text { Average for CIS-6 + } \\
\text { Georgia }\end{array}$} \\
\hline Georgia & 5.1 & 5.7 & 4.9 & 0.3 & 3.5 & 6.6 \\
\hline Average for Other CIS & 4.3 & 4.7 & 4.3 & 0.9 & 5.0 & 6.8 \\
\hline Average for SEE & 7.7 & 7.8 & 8.0 & 2.4 & 5.1 & 6.3 \\
\hline \multicolumn{7}{|l|}{ Average for CEE + } \\
\hline Baltics & 6.8 & 6.8 & 6.8 & 2.8 & 4.8 & 6.2 \\
\hline
\end{tabular}

Source: World Bank (2017b)

Well-functioning institutions and governance systems are crucial not only for financial development but also for economic growth. Because corruption and red tape are considered to be extremely detrimental to the functioning of an economy and increase the likelihood of a banking crisis (Mauro, 1998; Barth, Caprio, \& Levine, 1998), they should be kept at bay. In addition, a special role attaches to taxation and regulation and these should not become a burden or excessively restrict the financial system. The relevance of legal rules and law enforcement to the development of efficient financial markets was shown in the seminal work of La Porta et al. (1997). According to their study, legal systems that provide greater protection to creditors and investors facilitate access to external finance and corporate governance.

Demirgüç-Kunt and Maksimovic (1998) investigated how differences in legal and financial systems affect firms' use of external financing to fund growth. The authors showed that in countries with better legal systems, a greater proportion of firms used long-term external financing. The study also argued that established firms in countries with well-functioning institutions have lower profit rates. Beck, Demirgüç-Kunt, and Maksimovic (2005) researched the effect of financial, legal, and corruption problems on firms' growth rates. They found that size matters, and the smallest firms were the most constrained. The authors also found evidence that corruption of bank officials constrains the growth of firms. 
For all of the indicators of governance captured in Tables 14 and 15, CIS-6 + Georgia scores lower than the advanced transition countries. The only country in this region that is making some progress on governance indicators is Georgia. This backwardness in governance capacity could be one of the decisive factors still deterring development of the banking sector in CIS- 6 + Georgia.

Table 15. Governance indicators

\begin{tabular}{|c|c|c|c|c|c|c|c|c|c|}
\hline & \multicolumn{3}{|c|}{ Regulatory Quality } & \multicolumn{3}{|c|}{ Rule of Law } & \multicolumn{3}{|c|}{ Control of Corruption } \\
\hline & $\begin{array}{c}\text { Average } \\
1996- \\
2003\end{array}$ & $\begin{array}{c}\text { Average } \\
2004- \\
2008\end{array}$ & $\begin{array}{c}\text { Average } \\
2009- \\
2013\end{array}$ & $\begin{array}{c}\text { Average } \\
1996- \\
2003\end{array}$ & $\begin{array}{c}\text { Average } \\
2004- \\
2008\end{array}$ & $\begin{array}{c}\text { Average } \\
2009- \\
2013\end{array}$ & $\begin{array}{c}\text { Average } \\
1996- \\
2003\end{array}$ & $\begin{array}{c}\text { Average } \\
2004- \\
2008\end{array}$ & $\begin{array}{c}\text { Average } \\
2009- \\
2013\end{array}$ \\
\hline Armenia & -0.08 & 0.21 & 0.28 & -0.40 & -0.41 & -0.41 & -0.61 & -0.63 & -0.56 \\
\hline Azerbaijan & -0.85 & -0.48 & -0.39 & -1.01 & -0.79 & -0.80 & -1.09 & -1.03 & -1.08 \\
\hline Georgia & -0.67 & -0.06 & 0.63 & -1.24 & -0.49 & -0.12 & -0.97 & -0.30 & 0.05 \\
\hline Kyrgyz & & & & & & & & & \\
\hline Republic & -0.20 & -0.52 & -0.29 & -0.78 & -1.18 & -1.22 & -0.69 & -1.16 & -1.14 \\
\hline Moldova & -0.27 & -0.34 & -0.10 & -0.42 & -0.45 & -0.40 & -0.56 & -0.67 & -0.66 \\
\hline Tajikistan & -1.29 & -1.09 & -1.02 & -1.39 & -1.15 & -1.21 & -1.14 & -1.04 & -1.17 \\
\hline Uzbekistan & -1.85 & -1.54 & -1.58 & -1.21 & -1.27 & -1.31 & -1.00 & -1.00 & -1.24 \\
\hline $\begin{array}{l}\text { Average for } \\
\text { CIS- } 6+ \\
\text { Georgia }\end{array}$ & -0.74 & -0.55 & -0.35 & -0.92 & -0.82 & -0.78 & -0.87 & -0.83 & -0.83 \\
\hline $\begin{array}{l}\text { Average for } \\
\text { Other CIS }\end{array}$ & -0.73 & -0.63 & -0.61 & -1.01 & -0.93 & -0.80 & -0.92 & -0.84 & -0.90 \\
\hline $\begin{array}{l}\text { Average for } \\
\text { SEE }\end{array}$ & -0.26 & 0.01 & 0.19 & -0.63 & -0.45 & -0.26 & -0.61 & -0.37 & -0.31 \\
\hline $\begin{array}{l}\text { Average for } \\
\text { CEE }+ \\
\text { Baltics }\end{array}$ & 0.85 & 0.99 & 0.98 & 0.51 & 0.66 & 0.75 & 0.31 & 0.43 & 0.38 \\
\hline
\end{tabular}

Source: World Bank (2017c)

To sum up, for virtually all governance indicators, CIS-6 + Georgia performs worse than other groups. The only area in which this group of countries has achieved some progress was the depth of credit information. However, it would appear that the advance in this indicator has not been enough to offset institutional backwardness in other indicators. There seems to be a strong association between the lag in institutional development and the distrust in the banking sector of CIS- $6+$ Georgia previously noted.

\section{Economic development}

In this section, macroeconomic indicators (GDP per capita, annual GDP growth rate) for each transition country/grouping of countries are discussed. The economic performance is then linked with the findings on the performance of financial systems in various groups of transition economies. Because the prevailing opinion in the literature is that there is a link between economic growth and financial development, the expectation is that this relationship holds in the countries under consideration in this study. The conclusion will be drawn as to whether this is the case. 
The growth rates of GDP and GDP per capita in CIS-6 + Georgia during the period 19962013 were significantly higher than all other regions in the sample. However, even within this group significant differences are beginning to emerge. Thus, growth in GDP and GDP per capita in oil-rich Azerbaijan during this period outstripped similar indicators for the rest of the group by multiples of two or more. The economic performance of Armenia and Georgia has also been solid. Tajikistan started its economic rebuilding from the ruins of civil war, which is why this country's economic progress looks more impressive than some of its neighbors. However, despite this notable growth, the gap in GDP per capita between CIS-6 + Georgia and CEE + Baltics is still significant. Tables 16 and 17 illustrate the main economic growth indicators, GDP per capita and annual GDP growth rate, for the transition countries of CIS- 6 + Georgia, Other CIS, SEE, and CEE + Baltics.

Table 16. GDP per capita (in constant 2005 US\$), 1996-2013

\begin{tabular}{|c|c|c|c|c|c|}
\hline & $\begin{array}{c}\text { Average } \\
1996-2000\end{array}$ & $\begin{array}{c}\text { Average } \\
2001-2005\end{array}$ & $\begin{array}{c}\text { Average } \\
2006-2010\end{array}$ & $\begin{array}{c}\text { Average } \\
\text { 2011-2013 }\end{array}$ & $\begin{array}{c}\text { Average annual } \\
\text { growth rate in } \\
\%\end{array}$ \\
\hline Armenia & 802 & 1288 & 2034 & 2212 & 12.4 \\
\hline Azerbaijan & 750 & 1199 & 2731 & 3152 & 22.1 \\
\hline Georgia & 941 & 1264 & 1768 & 2069 & 9.1 \\
\hline Kyrgyz Republic & 392 & 456 & 540 & 596 & 4.1 \\
\hline Moldova & 598 & 722 & 930 & 1077 & 4.7 \\
\hline Tajikistan & 216 & 299 & 389 & 459 & 7.4 \\
\hline Uzbekistan & 423 & 496 & 668 & 846 & 7.0 \\
\hline $\begin{array}{l}\text { Average for CIS-6 + } \\
\text { Georgia }\end{array}$ & 589 & 818 & 1294 & 1487 & 9.5 \\
\hline Average for Other $\mathrm{CIS}$ & 2158 & 3017 & 4196 & 4744 & 8 \\
\hline Average for SEE & 2441 & 2947 & 3810 & 4101 & 4.4 \\
\hline $\begin{array}{l}\text { Average for CEE + } \\
\text { Baltics }\end{array}$ & 7777 & 9681 & 11984 & 12353 & 4.1 \\
\hline
\end{tabular}

Source: World Bank (2017a)

Table 17. Annual GDP growth rate, 1996-2013

\begin{tabular}{|c|c|c|c|c|c|}
\hline & $\begin{array}{c}\text { Average } \\
\text { 1996-2000 }\end{array}$ & $\begin{array}{c}\text { Average } \\
\text { 2001-2005 }\end{array}$ & $\begin{array}{c}\text { Average } \\
\text { 2006-2010 }\end{array}$ & $\begin{array}{c}\text { Average } \\
2011-2013\end{array}$ & $\begin{array}{c}\text { Average annual } \\
\text { growth rate in } \\
\% \\
\end{array}$ \\
\hline Armenia & 5.1 & 12.2 & 4.4 & 5.1 & 6.9 \\
\hline Azerbaijan & 7.1 & 13.7 & 16.9 & 2.7 & 10.9 \\
\hline Georgia & 5.9 & 7.4 & 5.3 & 5.6 & 6.1 \\
\hline Kyrgyz Republic & 5.6 & 3.8 & 4.5 & 5.5 & 4.8 \\
\hline Moldova & -2.3 & 7.1 & 3.3 & 5.0 & 3.1 \\
\hline Tajikistan & 0.5 & 9.8 & 6.6 & 7.4 & 5.9 \\
\hline Uzbekistan & 3.9 & 5.4 & 8.5 & 8.2 & 6.3 \\
\hline \multicolumn{6}{|l|}{ Average for CIS-6 + } \\
\hline Georgia & 3.7 & 8.5 & 7.1 & 5.6 & 6.3 \\
\hline Average for Other CIS & 2.2 & 7.9 & 4.7 & 3.6 & 4.7 \\
\hline Average for SEE & 5.8 & 5.0 & 3.7 & 1.6 & 4.5 \\
\hline \multicolumn{6}{|l|}{ Average for CEE + } \\
\hline Baltics & 4.3 & 5.3 & 1.8 & 1.9 & 3.5 \\
\hline
\end{tabular}

Based on the discussion above of the complex link between economic growth and financial development, we would expect accelerated economic growth in CIS-6 + 
Georgia to be associated with faster development of the financial sector in these countries. Indeed, it appears that high growth rates in the ratios of bank deposits to GDP, bank credit to GDP, and M2 to GDP were matched with high economic growth rates. However, as we saw in Section 3, almost all of the financial development indicators in CIS-6 + Georgia still demonstrate relatively underdeveloped financial systems. On the one hand, the strong growth appears to be associated with low starting points in CIS-6 + Georgia. This accords well with catch-up theory, which asserts that countries starting from a lower foundation grow faster to catch up with more advanced ones (Gerschenkron, 1962; Solow, 1956). On the other hand, the low absolute levels in the financial and economic development indicators appear to be due to institutional backwardness, inhibiting further financial and economic growth in CIS-6 + Georgia.

\section{Conclusion}

The existing theoretical and empirical literature largely favors a positive financial development-economic growth nexus. This paper aimed to identify the extent of the contribution of financial development to economic growth in the less-developed transition economies through the prism of comparisons of financial development and the evaluation of progress in the financial sector. We adopted Levine's (1997) functional approach in our analysis of financial system development. In particular, we studied how the less-developed transition economies, labeled CIS-6 + Georgia, compared to other transition economies in fulfilling the functions of: (i) savings mobilization; (ii) resource allocation; (iii) risk management facilitation; (iv) trading assistance; (v) exertion of corporate control. To assess each function, we applied a range of well-established proxy measures.

Despite having the highest average annual growth rates in the mobilization of deposits, the countries of CIS-6 + Georgia still generally lag behind in comparison to other transition economies. All CIS-6 + Georgia countries except Moldova have low ratios of bank deposits to GDP, which shows that the banking systems in those countries have been unable to attract funding in the form of deposits effectively. The analysis of real deposit rates, adjusted for inflation and outliers, demonstrates that the difference between CIS-6 + Georgia and the other groups of transition economies is not as significant as a decade ago. Because inflation and real interest rates in CIS-6 + Georgia are higher than in the other groups, it appears that banks in CIS-6 + Georgia have been successful in transferring the costs of higher prices and interest rates to their clients.

In terms of resource allocation, the less-developed transition economies of $\mathrm{CIS}+$ Georgia compare unfavorably with other transition economies in the ratio of private sector bank credit to GDP, the number of individual borrowers from commercial banks, 
and the percentage of firms using bank finance. Within the CIS-6 + Georgia group, the Central Asian republics fare particularly poorly. In contrast, and somewhat to our surprise, the proportion of non-performing loans in the group is quite small. This might be due to rather risk-averse and conservative behavior of the commercial banks in those countries.

With regard to risk management facilitation, the ratios of M2 to GDP, stock market capitalization to GDP and liquid assets were employed. The M2 to GDP ratio represents a proxy of the liquidity available to market participants and shows that less-developed countries had the most restricted access to such liquidity. For all of the CIS- $6+$ Georgia countries, with the exception of Moldova, this indicator was well below the averages in other transition economies. Stock markets continue to play a negligible role in the channeling of funds in all transition countries. Their significance in CIS-6 + Georgia is especially small. It should be noted that the size of the stock market in the majority of transition countries may be prohibitively small, rendering their further development a daunting task (Bonin \& Wachtel, 2003). Large, albeit declining, liquidity ratios show that banks in CIS-6 + Georgia remain relatively risk averse, with substantial holdings of liquid assets. This is likely to reflect less-developed interbank and money markets in those countries.

In respect of facilitating the trade in goods, services and contracts, once again the lessdeveloped countries of CIS-6 + Georgia show inferior results. The penetration of financial services in these less-developed transition economies is smaller, which means financial institutions in those countries have failed to establish convenient and low-cost payment facilities that would facilitate trade. For two of the three measures we used, ATMs per 100,000 population and bank accounts per 1,000 adults, CIS- 6 + Georgia showed the lowest averages by far. The exception was the number of bank branches per 100,000 adults. The average ratio for CIS- 6 + Georgia is slightly higher than for Other CIS, but still much lower than in the other groups. Closer inspection of the CIS- 6 + Georgia values reveals an outlier in the group: the figures for Uzbekistan exceeded those of any other transition country except Bulgaria but, upon further examination, it appears that the inconsistent classification of what constitutes a bank branch in Uzbekistan is the reason for such a high value.

With regards to the exertion of corporate control, we used broader governance indicators, including the strength of legal rights, depth of credit information, regulatory quality, rule of law, and control of corruption. Overall, these indicators demonstrated somewhat contradictory characteristics in the institutional progress of transition countries in both Central and Eastern Europe and the post-Soviet states. CIS-6 + Georgia achieved remarkable progress in the depth of credit information index and is now one of 
the leading groups on the basis of this coefficient. However, the performance of CIS-6 + Georgia in terms of strengthening the legal rights of borrowers and lenders is mixed. A majority of the countries in this group had good scores, and Georgia was the most improved country in terms of this parameter. By contrast, Tajikistan and Uzbekistan had the worst index ratings. As to the governance indicators, Georgia was the only country among the CIS-6 + Georgia group that improved its ratings. The divide between CIS- 6 + Georgia and the other groups of countries in transition is still wide and no significant signs of bridging this gap are in sight.

A review of macroeconomic indicators for these transition countries demonstrates that CIS-6 + Georgia have achieved significant progress in economic growth and an increase in GDP per capita. It was natural to expect similar progress in ratios measuring the development of the financial sector. Despite a significant improvement in many such indicators over time, the gap between development levels of the banking sectors of CIS$6+$ Georgia and most other transition countries is still significant. Further actions to strengthen the ability of financial systems to deliver their core functions should aid the economic growth in the CIS- 6 + Georgia countries, and close the gap between the levels of development among the transition economies. 


\section{References}

Acemoglu, D.; S. Johnson; and J. Robinson. 2005. "Institutions as a fundamental cause of longrun growth." In Handbook of Economic Growth, Volume 1A, ed. P. Aghion and S. Durlauf, pp. 385-472. Radarweg: Elsevier.

Akimov, A., and B. Dollery. 2008. "Financial policy in transition economies: architecture, pace, and sequencing." Problems of Economic Transition, vol. 50, no. 9, pp. 6-26.

Akimov, A. ,and B. Dollery. 2009. "Financial development policies in Uzbekistan: an analysis of achievements and failures." Economic Change and Restructuring, vol. 42, no. 4, pp. 293318.

Akimov, A.; A. Wijeweera; and B. Dollery. 2009. "Financial development and economic growth: evidence from transition economies." Applied Financial Economics, vol. 19, no. 12, pp. 999-1008.

Asian Development Bank. 2017. Key Indicators. Manila. Available at https://data.adb.org/search/field tags/key-indicators-751/type/dataset

Atje, R., and B. Jovanovic. 1993. "Stock markets and development." European Economic Review, vol. 37, no. 2, pp. 632-40.

Backé, P., and T. Zumer. 2005. "Developments in Credit to the Private Sector in Central and Eastern European EU Member States: Emerging from Financial Repression-A Comparative Overview." Focus, vol. (2005), no. 2, pp. 83-109.

Bagehot, W. 1873. Lombard Street: A description of the money market. London: Henry S. King.

Barth, J.; G. Caprio; and R. Levine. 1998. "Financial regulation and performance: cross-country evidence." World Bank Policy Research Working Paper, no. 2037. Washington, DC: World Bank

Beck, T.; A. Demirgüç-Kunt; and V. Maksimovic. 2005. "Financial and legal constraints to growth: Does firm size matter?" Journal of Finance, vol. 60, no.1, pp. 137-77.

Benhabib, J., and M. Spiegel. 2000. "The role of financial development in growth and investment." Journal of Economic Growth, vol. 5, no. 4, pp. 341-60.

Berglof, E., and P. Bolton. 2002. "The great divide and beyond: Financial architecture in transition." Journal of Economic Perspectives, vol. 16, no. 1, pp. 77-100.

Bonin, J.; I. Hasan; and P. Wachtel. 2005. "Bank performance, efficiency and ownership in transition countries." Journal of Banking and Finance, vol. 29, no. 1, pp. 31-53.

Bonin, J.; I. Hasan; and P. Wachtel. 2014. "Banking in transition countries." BOFIT Discussion Paper, no. 8/2014. Helsinki: Bank of Finland

Bonin, J., and P. Wachtel. 2003. "Financial sector development in transition economies: Lessons from the first decade." Financial Markets, Institutions and Instruments, vol. 12, no. 1, pp. 1-66.

Buiter, W., and A. Taci. 2005. "Capital account liberalization and financial sector development in transition countries." In Capital Liberalization and Transition Countries: Lessons from the Past and for the Future, ed. by A. Barker, and B. Chapple, pp. 105-41.Cheltenham: Elgar.

Burns, J., and B. Needles. 1994. Accounting Education for the 21st Century: The Global Challenges. London: Elsevier.

Calderón, C., and L. Liu. 2003. "The direction of causality between financial development and economic growth." Journal of Development Economics, vol. 72, no. 1, pp. 321-34.

Chinn, M., and H. Ito. 2006. "What matters for financial development? Capital controls, institutions, and interactions." Journal of Development Economics, vol. 81, no. 1, pp. 163-92.

De Haas, R.; Y. Korniyenko; A. Pivovarsky; and E. Loukianova. 2012. "Foreign banks and the Vienna Initiative: Turning sinners into saints?" EBRD Working Paper, no. 143, London: European bank for Reconstruction and Development. 
De Haas, R., and I. Van Lelyveld. 2006. "Foreign banks and credit stability in Central and Eastern Europe. A panel data analysis." Journal of Banking and Finance, vol. 30, no. 7, pp. 192752.

De Nicoló, G.; S. Geadah; and D. Rozhkov. 2003. "Bridging the" Great Divide"." Finance and Development, vol. 40, no. 4, pp. 42-45.

Demetriades, P., and K. Hussein. 1996. "Does financial development cause economic growth? Time-series evidence from 16 countries." Journal of Development Economics, vol. 51, no. 2, pp. 387-411.

Demirgüç-Kunt, A., and E. Detragiache. 1998. "Financial liberalization and financial fragility." IMF Working Paper, no. 98/83. Washington, DC: International Monetary Fund

Demirgüç-Kunt, A., and V. Maksimovic. 1998. "Law, finance, and firm growth." Journal of Finance, vol. 53, no. 6, pp. 2107-37.

Dermine, J., and P. Hillion. 1992. "Deposit Rate Ceilings and the Market Value of Banks: The Case of France, 1971-1981." Journal of Money, Credit and Banking, vol. 24, no. 2, pp. 184-94.

Djankov, S.; C. McLiesh; and A. Shleifer. 2007. "Private credit in 129 countries." Journal of Financial Economics, vol. 84, no. 2, pp. 299-329.

European Bank of Reconstruction and Development, 2017. Life in Transition Survey. London. Available at http://www.ebrd.com/what-we-do/economic-research-and-data/data/lits.html

Gerschenkron, A. 1962. Economic Backwardness in Historical Perspective: A Book of Essays. Cambridge, MA: Belknap Press of Harvard University Press

Goldsmith, R. 1969. Financial Structure and Development. New Haven: Yale University Press.

Gurley, J., and E. Shaw. 1967. "Financial structure and economic development." Economic Development and Cultural Change, vol. 15, no. 3, pp. 257-68.

Hassan, M.; B. Sanchez; and J. Yu. 2011. "Financial development and economic growth: New evidence from panel data." Quarterly Review of Economics and Finance, vol. 51, no. 1, pp. 88-104.

Hermes, N., and R. Lensink. 2000. "Financial system development in transition economies." Journal of Banking and Finance, vol. 24, no. 4, pp. 507-24.

International Monetary Fund. 2003. Report on Progress Under the CIS-7 Initiative.

Available at https://www.imf.org/external/np/eu2/2003/040703.htm

Jung, W. 1986. "Financial development and economic growth: international evidence." Economic Development and Cultural Change, vol. 34, no. 2, pp. 333-46.

King, R., and R. Levine. 1993a. "Finance and growth: Schumpeter might be right." Quarterly Journal of Economics, vol. 108, no. 3, pp. 717-37.

King, R., and R. Levine. 1993b. "Finance, entrepreneurship and growth." Journal of Monetary Economics, vol. 32, no. 3, pp. 513-42.

Klein, N. 2013. "Non-performing loans in CESEE: Determinants and impact on macroeconomic performance." IMF Working Paper. No. 13/72. Washington DC, International Monetary Fund

La Porta, R.; F. Lopez-de-Silanes; A. Shleifer; and R. Vishny. 1997. "Legal determinants of external finance." Journal of Finance, vol. 52, no. 3, pp. 1131-50.

Levine, R. 1997. "Financial development and economic growth: views and agenda." Journal of Economic Literature, vol. 35, no. 2, pp. 688-726.

Levine, R.; N. Loayza; and T. Beck. 2000. "Financial intermediation and growth: Causality and causes." Journal of Monetary Economics, vol. 46, no. 1, pp. 31-77.

Levine, R., and S. Zervos. 1998. "Stock markets, banks, and economic growth." American Economic Review, vol. 88, no. 3, pp. 537-58. 
Mauro, P. 1998. "Corruption: causes, consequences, and agenda for further research." Finance and Development, vol. 35, pp. 11-14.

McKinnon, R. 1973. Money and Capital in Economic Development. Washngton, DC: Brookings Institution Press.

McNulty, J., and J. Harper. 2012. "Obstacles to Financial Development in Transition Economies: A Literature Survey." Financial Markets, Institutions and Instruments, vol. 21, no. 4, pp. 203-40.

Merton, R., and Z. Bodie. 1995. "A conceptual framework for analyzing the financial system." In The Global Financial System: A Functional Perspective, ed. D. Crane, K. Froot, S. Mason, A. Perold, R. Merton, Z. Bodie, E. Sirri and P. Tufano, pp. 3-31. Boston: Harvard University Press

Odedokun, M. 1996. "Alternative econometric approaches for analysing the role of the financial sector in economic growth: Time-series evidence from LDCs." Journal of Development Economics, vol. 50, no. 1, pp. 119-46.

Ram, R. 1999. "Financial development and economic growth: Additional evidence." Development Studies, vol. 35, no. 4, pp. 164-74

Rousseau, P., and P. Wachtel. 1998. "Financial intermediation and economic performance: historical evidence from five industrialized countries." Journal of Money, Credit and Banking, vol. 30, no. 2, pp. 657-78.

Schumpeter, Joseph, and Ursula Backhaus. 2003. "The theory of economic development." Joseph Alois Schumpeter:61-116.

Solow, R. 1956. "A contribution to the theory of economic growth." Quarterly Journal of Economics, vol. 70, no. 1, pp. 65-94.

Stein, J. 1989. "Efficient capital markets, inefficient firms: A model of myopic corporate behavior." Quarterly Journal of Economics, vol. 104, no. 4, pp. 655-69.

Stiglitz, J., and A. Weiss. 1981. "Credit rationing in markets with imperfect information." American Economic Review vol. 71, no. 3, pp. 393-410.

Stiglitz, J., and A. Weiss. 1983. "Incentive effects of terminations: Applications to the credit and labor markets." American Economic Review, vol. 73, no. 5, pp. 91227.

Turley, G., and P. Luke. 2011. Transition Economics: Two Decades on. London and New York: Routledge.

World Bank. 2014. Uzbekistan Partnership: Country Program Snapshot. Washington, DC: World Bank.

World Bank, 2017a. Global Financial Development database. Washington, DC. Available at https://data.worldbank.org/data-catalog/global-financialdevelopment

World Bank, 2017b. World Development Indicators. Washington, DC. Available at http://wdi.worldbank.org/tables

World Bank, 2017c. Worldwide Governance Indicators. Washington, DC. Available at http://info.worldbank.org/governance/wgi/index.aspx\#home 